\title{
Game Media Design for Students' Banten Local Food Knowledge
}

\author{
Hepsi Nindiasari ${ }^{1 *}$, Nurhaidah Gailea ${ }^{2}$, Novaliyosi $^{3}$, Pipit Marianingsih $^{4}$, Ayrin $^{5}$ \\ ${ }^{1}$ Mathematic Education Postgraduate Department, University of Sultan Ageng Tirtayasa, Banten Indonesia \\ ${ }^{2}$ English Education Postgraduate Department, University of Sultan Ageng Tirtayasa, Banten Indonesia \\ ${ }^{3 / 5}$ Mathematic Education Department, University of Sultan Ageng Tirtayasa, Banten Indonesia \\ ${ }^{4}$ Biology Education Department, University of Sultan Ageng Tirtayasa, Banten Indonesia
}

*Email : hepsinindiasari@untirta.ac.id

\begin{abstract}
Banten Province has many local food, such as corn, Aren, and milkfish. The benefits of these local food is still largely unknown by school students in Banten Province. The developed of game interactive with local food content can be an interesting way as teaching learning media. The research aimed to produce learning media for students in improving local food knowledge in Banten Province through interactive game. The research methods conducted was research and development (R\&D), through steps: potential problems identification, collection of data, design, validation, revision, product trial, product revision, then field trial use to students, and final revision. This research has just produce the design of game media. The game content developed by questions or problems to be answered by the students about local food. The game itself called JABANREN interactive game, it was abbreviation for "JA" means JAGUNG (corn), "BAN" means BANDENG (milk fish), and "REN" means AREN (Aren).
\end{abstract}

Keywords: Game Media, Student, Local Food, Knowledge

\section{INTRODUCTION}

Interactive learning media is needed for students to improve their knowledge through interesting teaching and learning. The knowledge about local food, including corn, milk fish, and aren, is important for students in Banten Province, so that they can be implemented and motivated to consume those local foods in their daily life. Then, it will fulfill their nutritional needs and have an impact on food security.

Local food knowledge needs to be socialized to school students, so that as early as possible they know its benefits, including the nutrition contained in these foods and the how the way to process it into a delicious and healthy food. Local food knowledge gained by students, about corn, aren, and milkfish, is then expected increase their preference more than fast food which oftentimes they consume these days. As has been known ready-to-eat foods has less nutritional content and unhealthy as well consumed by students.

Based on field studies, school students in the Banten Province is less known about the benefits of local food sources such as corn, milkfish and aren. Furthermore, the textbook provided at school also contain less information about local food in Banten Province. Thus, it is required a learning media for facilitating the students to gain knowledge adjusted with their characteristics.

Educative media is important applied in school. There were several research that develop educational games, including the development of educational media for local 
food security by $[1,2,3,4$,$] , produce$ educational game media about the culinary by using Mangrove for children aged 8-12 years. [1] about making Flash Card learning media based on local wisdom and ethnobitany. [3] designed the NORICEMAN games as a learning media about food diversification and nutrition. Further, [5] developed learning media about local food for $4^{\text {th }}$ grade elementary students. Based on those research result, no one has developed an interactive educational games media to introduce local food in Banten, including corn, aren, and milkfish.

Interactive games are interesting to develop, because according to [3] revealed games is one of the media that is familiar to teenagers as well as the people's knowledge about technology nowadays as addition value to select games as learning media. Further, interactive and interesting media development is expected to change the user be more active and participate to utilize kinds of local food. In addition, the interactive media based on [2] interpreted as a tool that can deliver a message to others, individuals or groups, and generate mutual relationships among them. While, the questionnaires result conducted by [2] showed children prefer learning through the game to teacher's explanations or read theories by book. This opinion is also supported by [5] and [6].

In today's digital era, kids are more likely to choose computer-based media to play and look for learning references. Based on observation, students in school spend more time playing games through gadgets than offline media. Therefore, games can be more utilized when applied in learning due to its attractiveness, so as will improve students' academic performance, [7,8,6]. Moreover, Litbang Kemdikbud stated in this 21 st century require people to adapt with advances in information and technology, marked by the abundance of (1) information available anywhere and accessible at any time; (2) faster computing; (3) automation that replaces routine jobs; and (4) communication that can be done from anywhere and anywhere. So it is necessary to adjust the learning media given to the students [9]. Therefore, the purpose of this study os to develop interactive educational games to increase students' knowledge about local food.

\section{RESEARCH METHODS}

\subsection{Methods design}

The research methods conducted was research and development (R\&D), because it will produce an interactive educational games called JABANREN. it was abbreviation for "JA" means JAGUNG (corn), "BAN" means BANDENG (milk fish), and "REN" means AREN (aren). Targeted user was school student, aged 8 to 16 years old, elementary to high school. The research steps based through potential problems identification, collection of data, design, validation, revision, product trial, product revision, then field trial use to students, and final revision. In this research has just produce the design of game media (Figure 1).

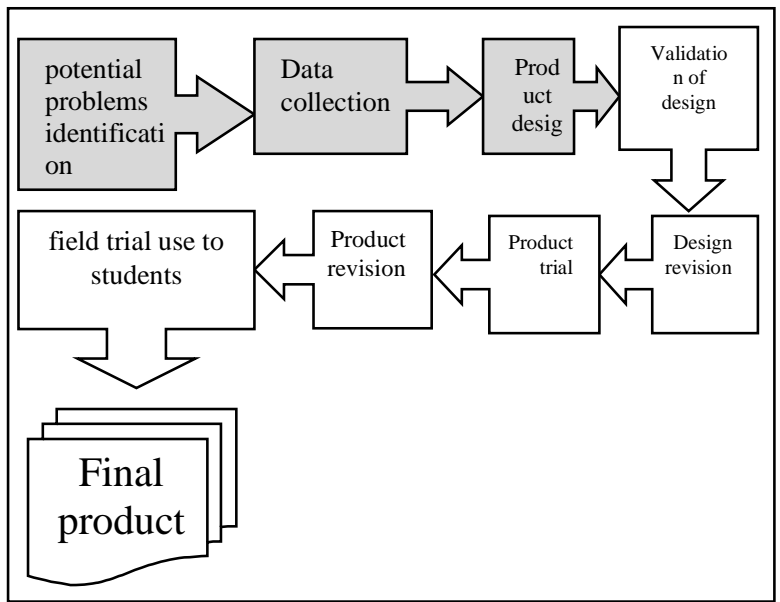

Figure 1. Interactive educational games 


\subsection{Product design}

The design of this product is still hypothetical, means the effectiveness of the product development has not been proven, which will be known after the tests. This research steps will produce new product design completed with specifications. While, the product design can be showed in the flow diagram on figure 2 .

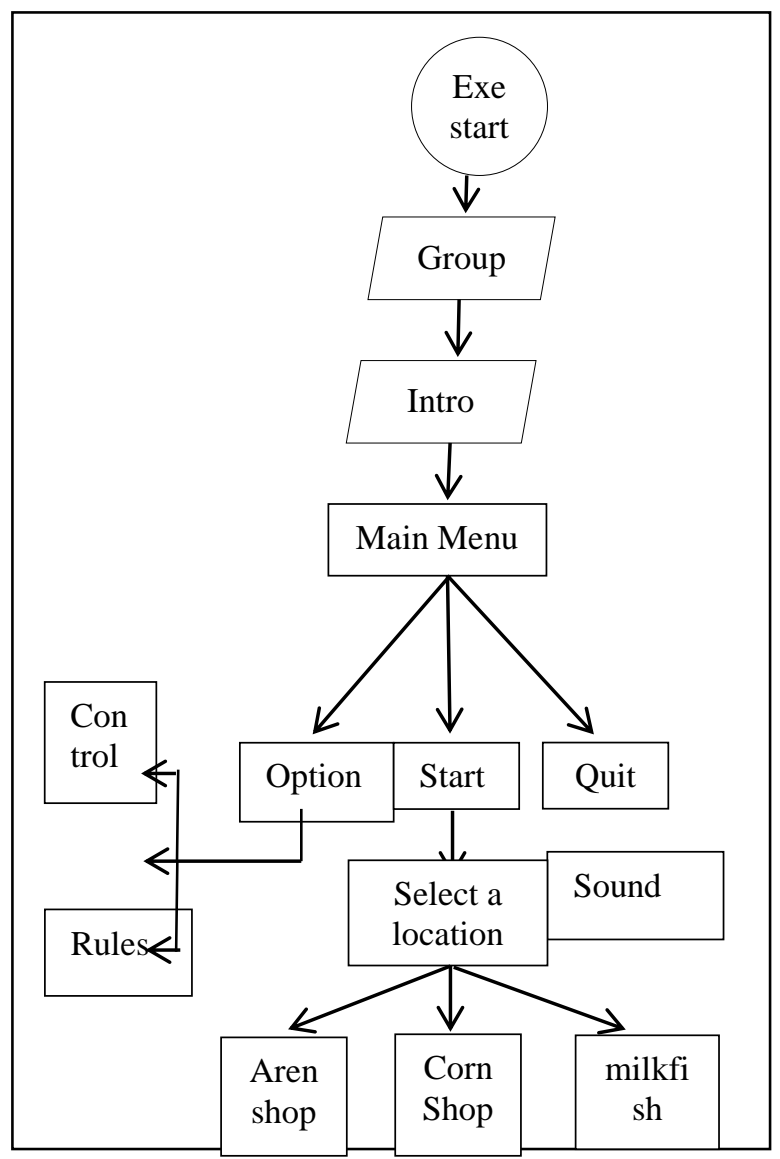

Figure 2. Flow diagram of games

The indicator of success in this research is the develop of design products interactive and educational JABANREN games to gain student's knowledge about Banten's local food (aren., corn, and milkfish), then declared good and feasible as teaching learning media, based on Puslitjaknov, if the game criteria has reached $70 \%$ on expert test.

\section{RESULTS AND DISCUSSION}

\subsection{Results}

Game Description Jabanren is made with ms.powerpoin application program combined with ispring application. The game is designed with powerpoint, while the question is made on the ispring menu in the mc application. Power point. After that, the game in publish in the form ofline web. To be opened on any computer. Once in publish, the game will contain Folders like below:

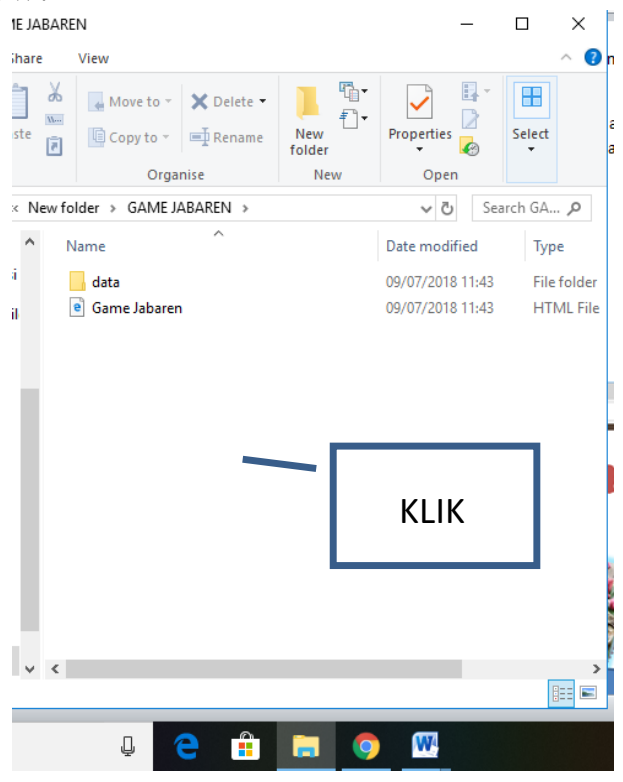

Figure 3. Jabanren folder after Publish.

The display in Jabanren games include: Opening, Home, start playing, game arrival.For more details can be seen in the picture below.

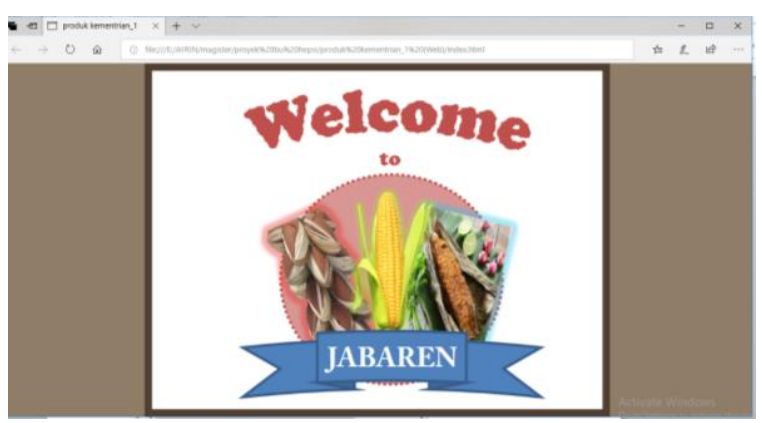

Figure 4. Opening, Jabanren Logo 
In the opening section, to be able to open Jabanren logo click. After that open Home, as shown below:

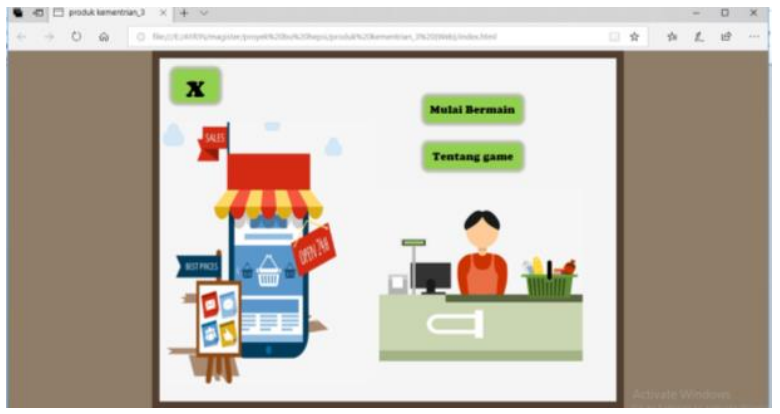

Figure 5. Home

Inside Home loading starts playing and about Game. If the student wants to play immediately then can click "start play", if you want first how the rules about the game can click "about Game". The menu starts playing loading about "select store". The store select menu contains a corn shop, a Badeng shop, and a palm sugar store. If you choose a corn shop will appear as shown in Figure 7.

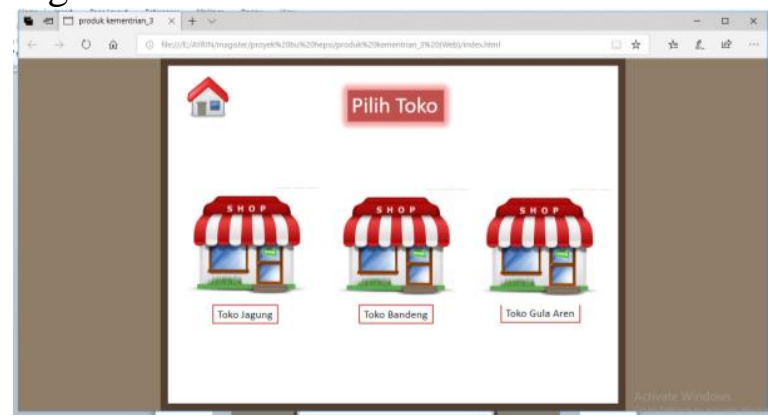

Figure 6. Select Store Menu

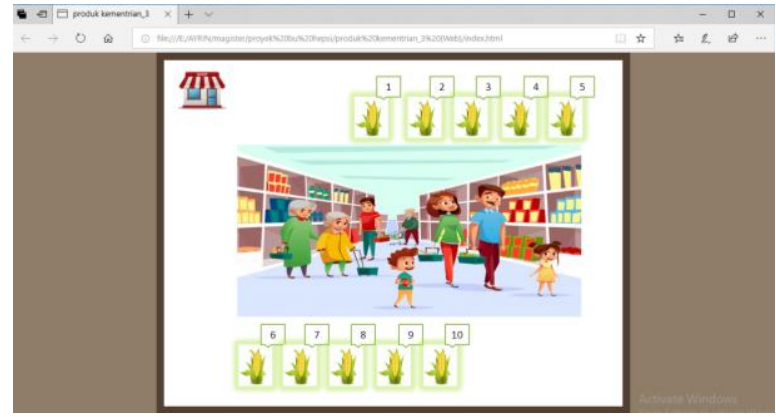

Figure 7. Corn Shop
Inside each store contains 10 questions about corn in the form of multiple choice if entered in the corn shop, palm sugar palen when entering the store, and milkfish if entered into a milk shop. This question or quiz contains questions which can solve the knowledge of students about the Banten local food. Knowledge gained contains indicators about the benefits, knowledge, processed food culinary, vitamins contained from local food corn, milkfish, and aren. To enter the quiz by clicking the corn image. If the student answers correctly it will appear tada "Correct". After the students answer and get a good score with a score of 100 for example, will appear congratulations you pass along with the score obtained.

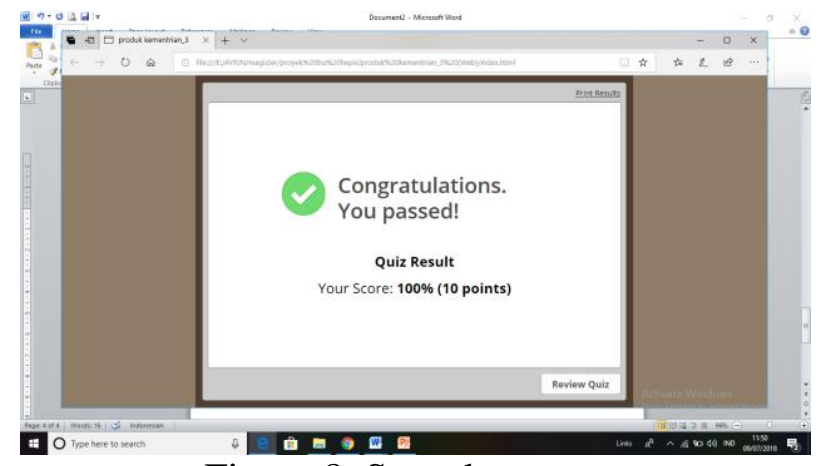

Figure 8. Speech on success

If the student has not been maxed out in answering, this game also gives students a chance to review the answer. If a student clicks on a game, a game rule will appear that includes Select where to play the game and collect points by answering the questions correctly.

\subsection{Discussion}

Game design has been made this attempt to attract school students in understanding food knowledge about corn, milkfish, and Aren This game is named JABANREN stands for Corn, Milk, and Aren. Efforts made for interested students are: games that contain quizzes, interesting images, giving the child 
an opportunity to self-evaluate, there is feedback, there is reward.

The game loads this quiz in which contains knowledge of the local food Banten corn, Aren, and milkfish. This knowledge will be the motivation of students to consciously try the local food preparations, because it already knows the usefulness in vitamins and other nutritional content. This attitude will create local food security especially in Banten. Motivation that was penetrated through the game media is in line with [10] and [11]. That gameplay provides an opportunity to play that can produce experience and games as an effective learning environment by integrating reflection into the play process resulting in an intrinsically motivational learning experience [10]. Similarly [10], [11] states that based on the results of his research the game can generate intrinsic motivation.

This JABANREN game is designed, poses challenges through problems to be solved, reflection clarity, memuculkan sense of student curiosity, game players can freely make choices by memuculkan buttons menu, the feedback shown by the students can megetahui correctness of answers selected then can review the answer. What has been published by this JABANREN Game has qualified as an Educational game. As has been described [10] educational games should introduce challenges, games that can create sensory and sensory curiosity, learners must feel control through feedback and games must use fantasy to reinforce instructional goals and stimulate previous interest from learners.

JABANREN game that contains interesting pictures in the selection of buttons made because it aims to attract the attention and interest of students. With the attention and interest of students, the message can be delivered easily and quickly. In addition, this designed GAME seeks to improve students' psychomotorism when students click the menu buttons and character formation, such as unyielding, curiosity, self regulation, motivation and so on. As the results of the study [2,3]. With the game being made are expected to be easily conveyed messages, psychomotor improvements, and character formation and local food security are realized.

\section{CONCLUSIONS AND RECOMMENDATIONS}

4.1 CONCLUSION

JABANREN game design includes the menu: Opener, Home in which there are 2 choices that select the store and about the game. Choose a store containing quizzes about corn, milkfish, and sugar. About the game includes game rules. The proposed quiz contains the problems - problems that become a challenge for students to deepen knowledge about corn, Aren and milkfish. Game created is expected to form the character of abstinence, motivation, self regulation learning. Game is expected to also realize the resilience of local pagan Banten, especially corn, milkfish, and Aren.

\subsection{SUGGESTION}

Extend the game through trial activities on the actual subject as well as dissemination. Game is a media that can be accepted by school students so that for educators to be able to prepare educational games in providing learning experiences to students. Educational games can also shape the character of students so as an alternative media provided learning.

\section{ACKNOWLEDGMENTS}

We wish to acknowledge and thank to the Postgruadete University of Sultan Ageng Tirtayasa (UNTIRTA) who has motivated and IDB (International Development Bank) which has funded this research. Grant IDB's grant research as an effort to realize 
UNTIRTA in food security in Banten Province.

\section{REFERENCES}

[1] Winda, (2015). Pengembangan Media Pembelajaran Flash Card Berbasis Kearifan Lokal Etnobotani Masyarakat Using di SMA Kabupaten Banyuwangi (Kelas X Pokok Bahasan Dunia Tumbuhan). Skripsi Pada Program Studi Pendidikan Biologi Jurusan MIPA, FKIP Universitas Jember. Universitas Jember: tidak diterbitkan.

[2] S, M. F., Y, E. C., Sn, S., Hum, M., Bambang, M., Sn, S., ... Siwalankerto, J. (2013.). Perancangan Media Permainan Edukatif mengenai Kuliner dari Pemanfaatan Mangrove untuk Anak Usia 8-12 Tahun.

[3] Niam, M., Mulyanto, E., Saputro, G. E., Desain, J., Visual, K., Komputer, F. I., \& Nuswantoro, U. D. (2013.). PERANCANGAN GAME ‘ NORICEMAN' SEBAGAI MEDIA, $1-8$.

[4] Sulhotony, dkk (2017). Pengembangan Media Pembelajaran Pengenalan Pangan Lokal untuk siswa kelas IV sekolah dasar

[5] Tifani, O. A., Putra, P. W., Shabrina, S. A., Herlin, E., Nuranisya, A., Rachman, A., ... Pamungkas, A. S. (2016). Teachers ' Readiness in Using Mobile Devices for Mathematics Teaching and Learning: A Case Study in Banten Province, Indonesia. In Mobile Learning, Emerging Learning Design \& Learning 2.0.

[6] Mc.Laren, et.all . (2017). A ComputerBased Game that Promotes Mathematics Learning More than a Conventional
Approach. International Journal of Game Based Learning (IJGBL)

[7] Papastergiou, M. (2009). Digital GameBased Learning in high school Computer Science education: Impact on educational effectiveness and student motivation. Computers \& Education, 52(1), 1-12. https://doi.org/10.1016/j.compedu.2008 .06 .004

[8] Zhang, M. (2015). Understanding the relationships between interest in online math games and academic performance. Journal of Computer Assisted Learning, 31(3), 254-267. https://doi.org/10.1111/jcal.12077

[9] Wijaya, E. Y., Sudjimat, D. A., Nyoto, A., \& Malang, U. N. (2016). Transformasi pendidikan abad 21 sebagai tuntutan pengembangan sumber daya manusia di era global, 1, 263278.S

[10] Paras, B., \& Bizzocchi, J. (2005). Game , Motivation, and Effective Learning : An Integrated Model for Educational Game Design.

[11] Habgood, M. P. J. (2010). Journal of the Learning Motivating Children to Learn Effectively: Exploring the Value of Intrinsic Integration in Educational Games, (January 2015), 37-41. https://doi.org/10.1080/10508406.2010. 508029 